\title{
17: 35697672-35712539
}

National Cancer Institute

\section{Source}

National Cancer Institute. 17:35697672-35712539. NCI Thesaurus. Code C41922.

Physical location of CDC6_Gene 